\title{
BURNOUT, DEPRESSION AND PROACTIVE COPING IN UNDERGROUND COAL MINERS IN SERBIA - PILOT PROJECT
}

Saska Manic ${ }^{1}$, Vladimir Janjic ${ }^{2,3}$, Slavica Djukic Dejanovic ${ }^{2,3}$, Aleksandar Aleksic ${ }^{4}$, Zeljka Aleksic ${ }^{5}$, Biljana Jaredic ${ }^{6}$, Mirjana Krkic ${ }^{7}$

${ }^{1}$ Department for Admission and Care of Medical Emergencies, Health Center Zajecar

${ }^{2}$ Psychiatric Clinic, Clinical Center Kragujevac

${ }^{3}$ Faculty of Medical Science, Kragujevac

${ }^{4}$ Department of Internal Medicine, Health Center Zajecar

${ }^{5}$ Department of Nuclear Medicine, Health Center Zajecar

${ }^{6}$ Faculty of philosophy, University of Priština with temporary head-office in Kosovska Mitrovica

Department of Internal Medicine, General Hospital Krusevac

\section{SINDROM SAGOREVANJA, DEPRESIJA I PROAKTIVNO PREVLADAVANJE KOD RUDARA RUDNIKA UGLJA U SRBIJI - PILOT PROJEKAT

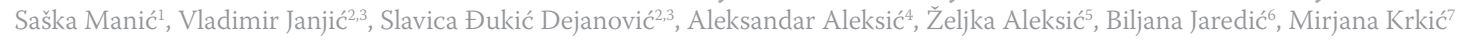 ${ }^{1}$ Služba za prijem i zbrinjavanje urgentnih stanja, Zdravstveni Centar Zaječar \\ ${ }^{2}$ Klinika za psihijatriju, Klinički centar Kragujevac \\ ${ }^{3}$ Fakultet medicinskih nauka, Kragujevac \\ ${ }^{4}$ Interno odeljenje Zdravstveni Centar Zaječar \\ 5 Nuklearna medicina, Zdravstveni Centar Zaječar \\ ${ }^{6}$ Filozofski fakultet, Univerzitet u Prištini sa privremenin sedištem u Kosovskoj Mitrovici}

Received / Primljen: 19.02.2016. ${ }^{7}$ Interno odeljenje, Opšta Bolnica Kruševac

Accepted / Prihvaćen: 17.04.2016.

\begin{abstract}
Mining is unsurprisingly considered a high-risk occupation because it involves continuous hard labour under highly demanding and stressful conditions. Many of these work stressors can impair individuals' well-being in both a physiological and psychological sense. The aims of this study were to assess the prevalence of burnout and depressive symptoms and to evaluate aspects of proactive coping among underground coal miners in Serbia. The study involved 46 male underground coal miners. Burnout was measured with the Copenhagen Burnout Inventory, depression was assessed with the Patient Health Questionnaire-9, and level of proactive coping was measured with the Proactive Coping Inventory. The results showed a low level of burnout syndrome among

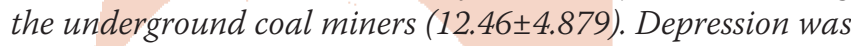

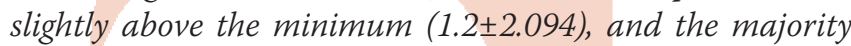
of the participants had no symptoms of depression (93.5\%). Overall, the underground coal miners' ability to proactively

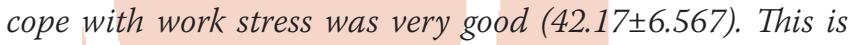
in contrast to the findings of the few previous international studies and is a good basis for further research using a larger sample in Serbia.
\end{abstract}

Keywords: underground coal miners, burnout, depression, proactive coping

\section{SAŽETAK}

Rudarstvo je neiznenadujuce smatrano profesijom visokog rizika s obzirom na to da podrazumeva obavljanje teškog rada u kontinuitetu, pod visoko zahtevnim i stresnim uslovima. Veliki broj ovih stresora na poslu može da naruši zdravlje pojedinca kako u fiziološkom tako i u psihološkom smislu. Cilj ovog istraživanja je bio pokušaj da se proceni prevalence sindroma sagorevanja i depresivnih simptoma, $i$ da se oceni u kojoj meri se rudari u Srbiji prilagodavaju svom radnom okruženju. Studija je obuhvatila 46 rudara podzemne eksloatacije uglja. Sindrom sagorevanja je meren uz pomoc Kopenhagen upinika o izgaranju, depresija je procenjena uz pomoc Upitnika o zdravlju pacijenata-9, a nivo proaktivnog prevladavanja meren je Skalom proaktivnog prevladavanja. Rezultati su pokazali da je sindrom sagorevanja kod rudara podzemne eksloatacije na

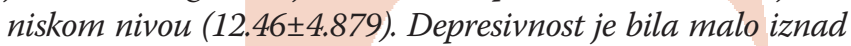

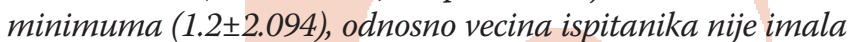
simptome depresije (93, 5\%). Ukupno proaktivno prevladavanje kod rudara podzemne eksloataije uglja je veoma dobro

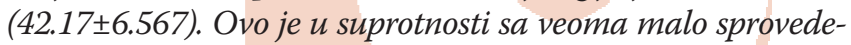
nih internacionalnih studija, a i dobra je osnova za dalje istraživanje na vecem uzorku u Srbiji.

Ključne reči: rudari podzemne eksploatacije uglja, sindrom sagorevanja, depresija, proaktivno prevladavanje

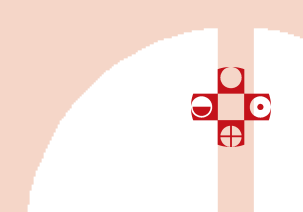

\section{ABBREVIATIONS}

CBI - Copenhagen Burnout Inventory DSM-V - Diagnostic and Statistical Manual of Mental Disorders, Fifth Edition
MBI - Maslach Burnout Inventory

PCI - Proactive Coping Inventory

PHQ-9 - Patient Health Questionnaire-9 


\section{INTRODUCTION}

Psychological well-being is an increasingly important issue that has, considerable implications for economic productivity, social cohesion, and individual health and happiness as well as and for the development of mental health disorders. The health of workers is important in determining the ability of employees to maintain productivity. Coping with work stress and managing depressive symptoms are crucial factors in enhancing mental health in the workplace, which may, in turn, boost the performance and even profits of organizations. Given that our country is in transition, the current technological situation in the mining industry and the industry's lack of consistency with world standards can influence the mental health well-being of employees.

Coal miners are exposed to a number of demanding daily job tasks and are among the workers with the highest incidence rate of occupational injury (1). Coal miners perform drilling and blasting operations; use chain and belt conveyors for coal hauling; work in confined spaces with narrow corridors, high ground pressures, and the potential for roof caveing; and work in the presence of the methane and oxidation processes in coal. Employees are also exposed to high temperatures in excess of $28^{\circ}$ Celsius, highly unionized environments $(2,3)$, noise, vibration, poor air quality, high humidity and cramped work spaces (4). Such a population group is interesting because it operates $24 / 7$ and is associated with significant psychosocial risk factors, including extended roster periods, shift work and high production demands (5).

A number of these stressors at work can impair an individual's well-being in both a physiological and psychological sense. The experience of occupational stress has been linked to negative individual outcomes such as high rates of depression and anxiety, burnout, secondary traumatic stress and reduced work performance (6). Underground coal miners have been found to suffer from more severe mental health problems than surface workers from the same coal mine (7). Thus, more attention should be paid to the protection of the mental health of underground miners.

Burnout syndrome in the workplace is characterized by mental or emotional exhaustion and fatigue, with a greater emphasis on psychological rather than physical symptoms. People suffering from burnout are excitable and overexcited, constantly tense, impulsive, and reserved; they often resort to alcohol or drugs; and they may express sadness, pessimism, emotional rigidity, hypersensitivity, helplessness, and despair. They may feel malaise and have undefined physical pains for longer periods of time (headaches, back pain, insomnia, upset stomach, etc.) (8). Given these symptoms of burnout, it is inevitable that the consequences will be manifested through negative work attitudes, low levels of performance $(9,10)$, low productivity, absenteeism and job turnover $(11,12)$, and these results have been found in all types of organizations.
Based on the nature of burnout, it is possible that working conditions may affect whether the state of burnout progresses into a clinically significant condition such as depression $(12,13)$. Depressed workers have high rates of absenteeism, presenteeism and even work cessation and turnover intention (14), which can be increased due to job tension, as well as decreased job satisfaction that can be exacerbated by consistently heavy workloads (11). They are more likely to abuse alcohol and drugs than those without depression (15). Moreover, the risk of an occupational injury experience is higher among workers who report depressive symptoms. If not recognized or treated, depression can profoundly impair workers' quality of life (4).

A potent mechanism for burnout and depression prevention is proactive coping. According to Schwarzer's proactive coping theory, proactive individuals aspire to improve themselves to avoid future adverse life situations rather than reacting passively (16). By engaging in proactive coping, individuals can recognize potential difficulties in their environments and address them before burnout occurs (17); thus, by developing a better ability to engage in proactive coping, one tends to experience fewer workplace stressors (18).

The aims of this study were to assess the prevalence of burnout and depressive symptoms and to evaluate aspects of proactive coping among underground coal miners in Serbia.

\section{SUBJECTS AND METHODS}

Study Design and Sample. This pilot project was designed as a cross-sectional survey and was conducted in a coal mine, Bogovina, in eastern Serbia, one of nine mines under the public company Resavica, which is involved in underground coal exploitation. The participants completed a set of self-administered questionnaires anonymously in the presence of researchers at the time of their health check-ups. The subjects were 52 male underground coal miners, 46 of whom returned valid questionnaires and were included in the study. The subjects gave signed written consent to participate in the study. They were given instructions for completing the questionnaire and the assurance that the study results would be used only for the purpose of writing a scientific paper. The participants did not write their names on their questionnaire answer sheets; therefore, their anonymity was guaranteed. The collected demographic characteristics included age, level of education, marital status and length of service.

The semi-structured questionnaire comprises five questions related to the injuries of miners and their colleagues, choice of workplace and impressions regarding risk and stress on the workplace; answer choices are "Yes" or "No".

The Copenhagen Burnout Inventory (CBI). This inventory was used because, in contrast to other burnout measures such as the Maslach Burnout Inventory (MBI), the CBI focuses exclusively on the dimension of exhaustion as 
the core characteristic of burnout (19). The seven work-related questions address the frustration and exhaustion associated with work. All of the questionnaire items have five response categories: always or to a very high degree, often or to a high degree, sometimes or somewhat, seldom or to a low degree, and never/almost never or to a very low degree. The responses in the present study were scaled from 0 to 100 for individual scores, and the scores were calculated by determining the means of the items in the scale. Total scores were also calculated: scores lower than 50 indicated low burnout $(<50)$, and scores higher than 50 ( $>50)$ indicated high burnout $(9,20-22)$.

The Patient Health Questionnaire-9 (PHQ-9). This inventory consists of nine questions based on the criteria for the diagnosis of major depressive disorder in the DSM-V. The subjects were asked to indicate the frequency of occurrence of each symptom over the past two weeks on a 4-point Likert scale (0: not at all; 1 : several days; 2 : more than half the days; and 3: nearly every day) (23). The scores for the nine questions were summed to give a total score ranging from 0 to 27, with higher scores indicating more severe depressive symptoms. Based on the total score, patients were categorized as having minimal depression (score 0-4), mild depression (score 5-9), moderate depression (score 10-14), moderately severe depression (score 15-19) or severe depression (score 20-27).

The Proactive Coping Scale. This scale is a part of the Proactive Coping Inventory (PCI) (24). It is a one of seven subscales of the PCI inventory; it consists of 14 items and has been translated into the Serbian language. This subscale combines autonomous goal setting with self-regulatory goal attainment cognition and behaviour. Typical items on the Proactive Coping Scale include: "I turn obstacles into positive experiences" and "After attaining a goal, I look for another, more challenging one". In scoring the responses, 1 is assigned to "not at all true", 2 to "barely true", 3 to "somewhat true" and 4 to "completely true". The total score represents the general level of proactive coping, with higher scores indicating more proactive coping.

Statistical analysis: The obtained research data were statistically processed using SPSS v. 18 for Windows. A descriptive analysis was performed to examine the sample and the answer for every question separately and to measure average values for the scales. The variable results are presented as the means, minimums, maximums and standard deviations. The reliability of the scales was measured using the Cronbach's alpha coefficient. An independent-samples t-test was applied to compare the average values of specific inventories with the questions from the semi-structured interviews, whereas the arithmetic means of three or more variables were compared using an analysis of variance (ANOVA). Pearson's correlation coefficient ( $r$ ) was used to scale the direction and strength of a linear relationship between two variables. The level of significance was $\mathrm{p}<0.05$ in the applied analytical methods.

\section{RESULTS}

The internal consistency obtained for our sample with regard to the Copenhagen Burnout Inventory was good $(\alpha=.823)$, and it was low but acceptable $(\alpha=.77)$ for the Patient Health Questionnaire - 9 and the Proactive Coping Scale $(\alpha=.73)$.

This research included 46 underground coal miners, all of whom were male. The mean age of the participants was $43.7 \pm 7.47$ years. The total years of service were $25.78 \pm 6.728$, and the years of service as a miner in the current workplace were $15.65 \pm 9.243$. Most of the participants had a high school diploma 54.3\%, 43.5\% had finished elementary school and $2.2 \%$ had finished college. The largest proportion was married (93.5\%), and 6.5\% were single; none of the miners was divorced (Table 1 ).

Most of them $(63,0 \%)$ had been not injured in the workplace in such a way that required them to go on sick leave, and $52.2 \%$ of the miners had attended to the injuries of colleagues in the workplace. Most of them were employed in the mine because they had no other workplace from which to choose (52\%). Half of them thought that their workplace was stressful and 52\% thought that their workplace was highly risky (Table 2).

Table 1. Demographic data of coal miners

\begin{tabular}{|c|c|c|c|}
\hline & & Mean & s.d. \\
\hline \multicolumn{2}{|l|}{ Age } & 43.78 & 7.474 \\
\hline \multicolumn{2}{|c|}{ Total years of service } & 25.78 & 6.828 \\
\hline \multicolumn{2}{|c|}{ Years of service in the current workplace } & 15.65 & 9.243 \\
\hline & & \multicolumn{2}{|l|}{$\mathrm{N}(\%)$} \\
\hline \multirow{3}{*}{ Education } & elementary school & \multicolumn{2}{|c|}{$20(43.5 \%)$} \\
\hline & high school diploma & \multicolumn{2}{|c|}{$25(54.3 \%)$} \\
\hline & college & \multicolumn{2}{|c|}{$1(2.2 \%)$} \\
\hline \multirow{3}{*}{ Marital status } & single & \multicolumn{2}{|c|}{$3(6.5 \%)$} \\
\hline & married & \multicolumn{2}{|c|}{$43(93.5 \%)$} \\
\hline & divorced & \multicolumn{2}{|c|}{$0(0 \%)$} \\
\hline
\end{tabular}

s.d. - standard deviation; $\mathrm{N}$ - number of subjects

Table 2. Semi-structured interview analysis

\begin{tabular}{|l|l|l|}
\hline \multicolumn{1}{|c|}{ Questions } & \multicolumn{2}{c|}{ Answers } \\
\hline & N (\%) & No $(\%)$ \\
\hline $\begin{array}{l}\text { Have you been injured in the workplace } \\
\text { in a way that required you to go on sick } \\
\text { leave? }\end{array}$ & $17(37 \%)$ & $29(63 \%)$ \\
\hline $\begin{array}{l}\text { Have you attended to the injuries of } \\
\text { colleagues in the workplace? }\end{array}$ & $24(52 \%)$ & $22(47.8)$ \\
\hline $\begin{array}{l}\text { Are you employed here because you have } \\
\text { no other workplace from which to choose? }\end{array}$ & $24(52 \%)$ & $22(47.8)$ \\
\hline $\begin{array}{l}\text { Do you think that your workplace is } \\
\text { highly risky? }\end{array}$ & $24(52 \%)$ & $22(47.8)$ \\
\hline $\begin{array}{l}\text { Do you feel that your workplace is } \\
\text { stressful? }\end{array}$ & $23(50 \%)$ & $23(50 \%)$ \\
\hline
\end{tabular}

$\mathrm{N}$ - number of subjects 
Table 3. Descriptive statistics of the items in the burnout, depression and proactive coping scales

\begin{tabular}{|l|l|l|l|l|l|}
\hline & N & Min. & Max. & Mean & s.d. \\
\hline Burnout & 46 & 7 & 26 & 12.46 & 4.870 \\
\hline Depression & 46 & 0 & 10 & 1.20 & 2.094 \\
\hline Proactive coping & 46 & 27 & 56 & 42.17 & 6.567 \\
\hline
\end{tabular}

$\mathrm{N}$ - number of subjects; Min. - minimum; Max. - maximum; s.d. - standard deviation;

In Table 3, the total scores for the burnout, depression and proactive coping scales are presented using descriptive statistics. The results showed that burnout was present

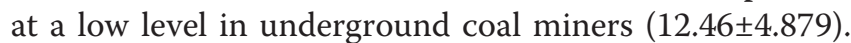

Depression was slightly above the minimum $(1.2 \pm 2.094)$ Overall, the underground coal miners' ability to proactively cope with work stress was very good (42.17 \pm 6.567$)$.

By analysing the PHQ-9 scores for depression severity using descriptive statistics, we found that the majority of the underground coal miners had no symptoms of depression (93.5\%); mild depression scores were found in $4.3 \%$ of the miners, and $1(2.2 \%)$ underground coal miner showed symptoms of moderate depression (Fig. 1).

The results from the questionnaire used for the self-assessment of proactive coping ability are presented for each question and all of the respondents in Table 4. The results obtained by analysing the data from the questionnaire indicated that the majority of the re-

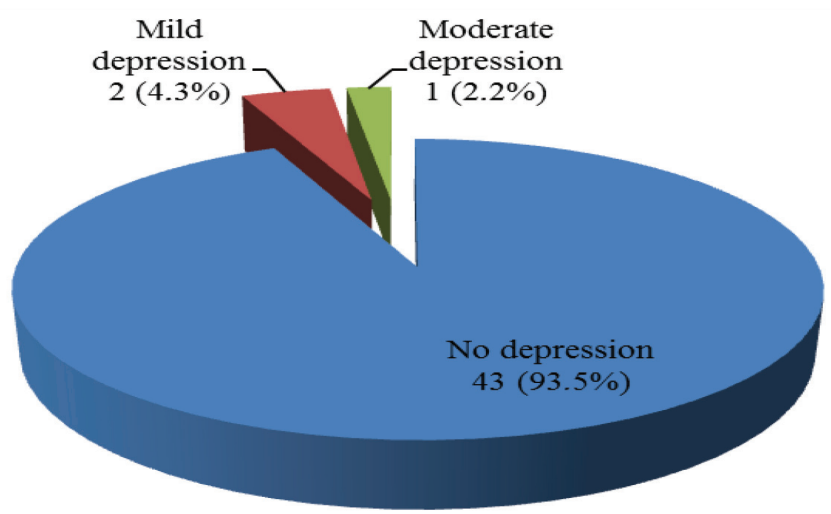

Fig. 1. Depression severity according to the PHQ-9 inventory

Table 4. Proactive Coping Inventory data

\begin{tabular}{|c|c|c|c|c|c|}
\hline \multirow{2}{*}{\multicolumn{2}{|c|}{ Questions }} & \multicolumn{4}{|c|}{ Answers N (\%) } \\
\hline & & \multirow{2}{*}{$\frac{\text { "not at all true" }}{3(6.5 \%)}$} & \multirow{2}{*}{$\begin{array}{c}\text { "barely true" } \\
0(0 \%)\end{array}$} & \multirow{2}{*}{$\begin{array}{c}\text { "somewhat true" } \\
6(13.0 \%)\end{array}$} & \multirow{2}{*}{$\begin{array}{c}\text { "completely true" } \\
37(80.4 \%)\end{array}$} \\
\hline 1 & I am a "take charge" person & & & & \\
\hline 2 & I try to let things work out on their own & $19(41.3 \%)$ & $18(39.1 \%)$ & $3(6.5 \%)$ & $6(13.0 \%)$ \\
\hline 3 & After attaining a goal, I look for another, more challenging one & $3(6.5 \%)$ & $9(19.6 \%)$ & $10(21.7 \%)$ & $24(52.2 \%)$ \\
\hline 4 & I like challenges and beating the odds & $20(43.5 \%)$ & $1(2.2 \%)$ & $8(17.4 \%)$ & $17(37.0 \%)$ \\
\hline 5 & I visualise my dreams and try to achieve them & $3(6.5 \%)$ & $3(6.5 \%)$ & $15(32.6 \%)$ & $25(37.0 \%)$ \\
\hline 6 & $\begin{array}{l}\text { Despite numerous setbacks, I usually succeed in getting } \\
\text { what I want }\end{array}$ & $4(8.7 \%)$ & $8(17.4 \%)$ & $18(39.1 \%)$ & $16(34.8 \%)$ \\
\hline 7 & I try to pinpoint what I need to succeed & $4(8.7 \%)$ & $5(10.9 \%)$ & $10(21.7 \%)$ & $27(58.7 \%)$ \\
\hline 8 & $\begin{array}{l}\text { I always try to find a way to work around obstacles; nothing } \\
\text { really stops me }\end{array}$ & $2(4.3 \%)$ & $4(8.7 \%)$ & $22(47.8 \%)$ & $18(39.1 \%)$ \\
\hline 9 & I often see myself failing so I don't get my hopes up too high & $10(21.7 \%)$ & $16(34.8 \%)$ & $14(30.4 \%)$ & $6(13.0 \%)$ \\
\hline 10 & When I apply for a position, I imagine myself filling it & $4(8.7 \%)$ & $4(8.7 \%)$ & $14(30.4 \%)$ & $24(52.2 \%)$ \\
\hline 11 & I turn obstacles into positive experiences & $5(10.9 \%)$ & $2(4.3 \%)$ & $13(28.3 \%)$ & $26(56.5 \%)$ \\
\hline 12 & $\begin{array}{l}\text { If someone tells me I can't do something, you can be sure I } \\
\text { will do it }\end{array}$ & $5(10.9 \%)$ & $11(23.9 \%)$ & $19(41.3 \%)$ & $11(23.9 \%)$ \\
\hline 13 & $\begin{array}{l}\text { When I experience a problem, I take the initiative in } \\
\text { resolving it }\end{array}$ & $3(6.5 \%)$ & $2(4.3 \%)$ & $4(8.7 \%)$ & $37(80.4 \%)$ \\
\hline 14 & $\begin{array}{l}\text { When I have a problem, I usually see myself in a no-win } \\
\text { situation }\end{array}$ & $21(45.7 \%)$ & $4(8.7 \%)$ & 8 (17.4\%) & $13(28.3 \%)$ \\
\hline
\end{tabular}

$\mathrm{N}$ - number of subjects 
Table 5. Correlation analysis between variables

\begin{tabular}{|c|c|c|c|c|c|c|}
\hline \multicolumn{7}{|c|}{ Correlations } \\
\hline Pearson correlation & Age & $\begin{array}{c}\text { Total years of } \\
\text { service }\end{array}$ & $\begin{array}{l}\text { Years of } \\
\text { service in } \\
\text { the current } \\
\text { workplace }\end{array}$ & $\begin{array}{c}\text { Proactive } \\
\text { coping }\end{array}$ & Depression & Burnout \\
\hline Age & 1 & $.686^{* *}$ & .138 & .128 & .143 & -.155 \\
\hline Total years of service & $.686^{* * *}$ & 1 & .249 & -.063 & $.298^{*}$ & -.179 \\
\hline Years of service in the current workplace & .138 & .249 & 1 & -.204 & .339 & -.215 \\
\hline Proactive coping & .128 & -.063 & -.204 & 1 & $-.368^{*}$ & -.089 \\
\hline Depression & .143 & $.298^{*}$ & .339 & $-.368^{*}$ & 1 & -.159 \\
\hline Burnout & -.155 & -.179 & -.215 & -.089 & -.159 & 1 \\
\hline
\end{tabular}

** Correlation is significant at the 0.01 level (2-tailed).

* Correlation is significant at the 0.05 level (2-tailed).

spondents were "take charge" individuals (37, 80.4\%) and that very few of them did not try to find a way to work around obstacles (2, 4.3\%).

The results of the correlation analysis of the total scores for each scale are shown in Table 5 . The results showed that coal miners became more depressed with more total years of service and more years of service in the current workplace. In contrast, coal miners with higher levels of proactive coping were less depressed. In addition, no significant correlations were found between burnout and age, burnout and total years of service and burnout and years of service in the current workplace, or between depression and burnout (sig. at 0.05 and 0.01 ).

An independent-samples T-test was used in the comparison of the measurements of depression, burnout and proactive coping based on questions from the semi-structured interviews. Statistically significant differences $(\mathrm{p}<0.05)$ were found only for the underground coal miners who were employed in the mine because they had no choice of another workplace; no significant differences were found for the participants who were employed in the mine by choice.

Using an ANOVA test, we compared the measurements of depression, burnout and proactive coping with the participants' levels of education and found no influence from the level of education on burnout, depression or proactive coping.

\section{DISCUSSION}

This study showed that burnout syndrome in underground coal miners is at a low level and that the majority of participants did not exhibit depressive symptoms. Overall, underground coal miners' proactive coping levels are very good.

The study of mental health in the mining industry is a useful proxy for the health status of such employees and helps to identify occupational health hazards. The health of workers is important in determining the ability of employees to maintain productivity. Hence, underground coal miners are especially prone to occupational health problems and are among the workers with the highest incidence rates of occupational injury (1) because they spend every work hour in a demanding work environment that may have an impact on their well-being.

Very few studies devoted to the issues studied in this paper were found in the available databases. It is therefore difficult to compare the obtained test results with those of other related studies of these aspects of mental health in underground coal miners.

Researchers from South Africa examined the organizational burnout of employees in various working positions in the mining industry. A study by Horn C.R. showed low to moderate levels of exhaustion, cynicism and reduced professional efficacy as subdimensions of burnout among mid-level managers in an underground coal mine (25). Van der Walt et al found that the predictors of burnout were job demands, overload and a lack of advancement opportunities in the workplace (26). Another study conducted by Roets $\mathrm{H}$. showed that a weak sense of coherence combined with job stress was associated with all three components of burnout (27).

Uysal H.T. and Kesim E. measured organizational burnout in blue-collar workers employed by Turkish Hard Coal Enterprise. They found that the burnout levels of workers were not significantly different according to their working positions (casual workers, technical staff, engineers); however, there were significant differences with regard to the miners' working locations (underground or above ground) and places (different coal mines in Turkish Hard Coal Enterprise) (28).

The underground coal miners in our research showed lower levels of burnout syndrome than workers in other professions in Serbia. However, studies have found high scores for both personal and work-related burnout among manufacturing workers in the food industry in Serbia (29). Moderate to high levels of burnout syndrome were found among orthopaedic surgeons (30), general practitioners $(30,31)$ and psychiatrists (31). Stanetić K, et al's study results showed that levels of stress and emotional exhaustion increase with length of service and age. In that study, the highest levels of stress and emotional exhaustion were 
found among the oldest physicians with the greatest length of service, whereas the lowest levels were found among the youngest physicians with the shortest length of service (8). In contrast, our research showed no correlations between length of service and burnout and age and burnout.

Lui L, et al showed that $62.8 \%$ of underground coal miners in China suffered from depression (4). This is in contrast to our research, in which $93.5 \%$ of the coal miners had no symptoms of depression. Another Chinese study indicated that workers in the mining industry had symptoms of depression and anxiety and that underground coal miners were found to suffer from more severe mental health problems than surface workers from the same coal mine (32). Marchand A. examined mental health among different occupations in Canada and found that workers reported poorer mental health in twenty selected occupations; the mining industry was among the occupations with lowest prevalence of mental health risks in the sample (33). Similar results were presented by McLean, who conducted qualitative research on 10 residents mine workers in Australia (34).

Our results showed that level of depression increased with length of service and was higher for those who were employed in the mine because they had no other choice of workplace. On the other hand, those who coped better with stress were less depressive. Proactive coping was found to be negatively correlated with depression, which indicates that miners with high levels of proactive coping ability have low levels of depression.

Regardless of the features of their demanding workplace, underground coal miners' proactive coping ability is high. Our results showed that the miners saw themselves as "take charge" individuals; therefore, it can be said that they perceive difficult situations as challenges rather than as threats. This refers to the belief that they have the ability overcome the difficulties of their work environment, which may involve making a plan of action (16). Many of the respondents $(80.4 \%)$ declared that they take the initiative in resolving a problem when they encounter it. The same per cent stated that they do not let things work out on their own, which confirms that underground coal miners are prepared to take action. Successful action is more likely to be taken if one feels confident and prepared enough to control challenges or threats (16). Respondents considered their workplace highly risky and stressful, but the majority stated that they could easily turn obstacles into positive experience (84.8\%) and that nothing could stop them from finding a way to work around obstacles (86.9\%). The demonstrated high level of proactive coping confirms their empowerment to face future adverse situations and react proactively to solve problems. They showed equally high levels of self-determination in goal setting behaviours: they saw how to successfully achieve desirable goals and, after that, how to look for another, more engaging goal. Proactive coping consists of the accumulation of various resources and the attainment of skills such as organization, planning, goal-setting and mental simulation (17).
Even though slightly more than a half of the examined coal miners reported that they were employed in the mine because they could not find a job of their own choice, there was no statistically significant difference in proactive coping between those workers and workers who were employed in the mine by choice. However, there was a statistically significant difference between these two groups in terms of depression; we found that that group of miners who were employed in the mine because they could not find a job of their own choice were significantly more depressed than the other group. Overall, despite the influence of job choice on their mood changes, the underground coal miners very proactively performed their activities in a demanding work environment and thus reported lower levels of burnout (16). Challenges stimulate vitality, which leads to positive outcomes and indicates healthy functioning (16). The positive moods of these underground coal miners may help them to perceive obstacles as challenges and to overcome workplace dangers.

The limitations of the study relate to its cross section design and its small sample size as well as to having beenand because the sample was drawn from one coal mine. Because it was conducted during the miners' health check-ups, they may have modified their answers to appear be healthy and complain less. In addition, there was no control group with which to compare the results. Despite these limitations, this study serves as a starting point for developing further initiatives in this area that consider cultural specifics such as rural environments and continuous work throughout generations.

\section{CONCLUSION}

The results of this pilot project showed that among underground coal miners, there is a very low level of burnout, depression is absent and the level of proactive coping is high. The results relating to well-being in these aspects of underground coal miner's mental health, which are in contrast to previously conducted international studies, are a good basis for further research in the field. Considering that the obtained results were inconsistent with the expected results, the research variables should be expanded and examined further to determine how they influence miners' mental health. Further research is needed using a bigger sample that includes other coal mines in Serbia.

\section{REFERENCES}

1. Bhattacherjee, A. Bertrand, J.P. Meyer, J.P. Benamghar, L. Otero Sierra, C. Michaely, J.P. et al. (2007). Relationships of physical job tasks and living conditions with occupational injuries in coal miners. Ind Health. 45(2), 352-8. 
2. Stojadinović, S. et al. (2012). Mining injuries in Serbian underground coal mines - A 10-year study. Injury. 43(12), 2001-5. DOI: 10.1016/j.injury.2011.08.018.

3. Brand-Labuschagne, L. Mostert, K. Rothmann, S. Jnr \& Rothmann, J.C. (2012). Burnout and work engagement of South African blue-collar workers: The development of a new scale. Southern African Business Review. 16(1), 58-93.

4. Liu, L.Wang, L. \& Chen, J. (2014). Prevalence and Associated Factors of Depressive Symptoms among Chinese Underground Coal Miners. Biomed Res Int. 2014: 987305. DOI: 10.1155/2014/987305.

5. Carlisle, K.N. \& Parker, A.W. (2014). Psychological Distress and Pain Reporting in Australian Coal Miners. Safety and Health at Work. 5(4), 203-9. DOI: 10.1016/j. shaw.2014.07.005

6. Rees, C.S. Breen, L.J. Cusack, L. \& Hegney, D. (2015). Understanding individual resilience in the workplace: the international collaboration of workforce resilience model. Front Psychol. Feb 4;6:73. DOI: 10.3389/ fpsyg.2015.00073. eCollection 2015

7. Liu, L. Wen, F. Xu, X. \& Wang, L. (2015). Effective resources for improving mental health among Chinese underground coal miners: Perceived organizational support and psychological capital. J Occup Health. 57(1), 58-68. DOI: 10.1539/joh.14-0082-OA.

8. Stanetić, K. \& Tešanović, G. (2013). Influence of age and length of service on the level of stress and burnout syndrome. Med pregl. 66(3-4), 153-162. DOI: 10.2298/ MPNS1304153S

9. Bakker, A.B. Emmerik, H.V. \& Riet, P.V. (2008). How job demands, resources, and burnout predict objective performance: a constructive replication. Anxiety, Stress and Coping. 21(3), 309-324. DOI: 10.1080/10615800801958637.

10. Simmons, B. Gooth, J. Nelson, D.L. \& Little, L.M. (2009). Secure attachment: implications for hope, trust, burnout, and performance. Journal of Organizational Behavior. 30(2), 233-247. DOI: 10.1002/job.585.

11. Hayes, L.J. O’Brien-Pallas, L. Duffield, C. et al. (2006). Nurse turnover: a literature review. International Journal of Nursing Studies. 43(2), 237-263. DOI: http://dx. doi.org/10.1016/j.ijnurstu.2005.02.007

12. Maslach, C. Schaufeli, W.B. \& Leiter, M.P. (2001). Job burnout. Annu Rev Psychol. 52:397-422. DOI: 10.1146/ annurev.psych.52.1.397.

13. Ahola, K. \& Hakanen, J. (2014). Burnout and health. In: Leiter, M.P, Bakker, A.B \& Maslach, C. (Eds.), Burnout at work - a psychological perspective. (pp.10-31). Hove, East Sussex: Psychology Press.

14. Lerner, D. Adler, D. A. Chang, H. et al. (2004). Unemployment, job retention, and productivity loss among employees with depression. Psychiatric Services. 55(12), 1371-1378. DOI:10.1176/appi.ps.55.12.1371.

15. Regier, D. A, Farmer, M. E. Rae, D. S. et al. (1990). Comorbidity of mental disorders with alcohol and other drug abuse. Results from the Epidemiologic Catchment
Area (ECA) Study. The Journal of the American Medical Association. 264(19), 2511-2518. DOI:10.1001/ jama.1990.03450190043026.

16. Greenglass, E.R. \& Fiksenbaum, L. (2009). Proactive Coping, Positive Affect, and Well-Being. European Psychologist. 14(1), 29-39. DOI 10.1027/10169040.14.1.29

17. Chang, Y. \& Chan, H.J. (2015). Optimism and proactive coping in relation to burnout among nurses. Journal of Nursing Management. 23(3), 401-8. DOI: 10.1111/ jonm.12148.

18. Zhou, Z. E., Yang, L.Q., \& Spector, P. E. (2015). Political Skill: A Proactive Inhibitor of Workplace Aggression Exposure and an Active Buffer of the Aggression-Strain Relationship. Journal of Occupational Health Psychology. 20(4), 405-19. DOI: $10.1037 / \mathrm{a} 0039004$.

19. Madsen, I.E.H., et al. (2015). Burnout as a risk factor for antidepressant treatment - a repeated measures timeto-event analysis of 2936 Danish human service workers. Journal of Psychiatric Research. 65:47-52. DOI: 10.1016/j.jpsychires.2015.04.004.

20. Hutchinson, J.R., White, S.G. \& McBrock, D. (2007). The intersection between caregiver responsibilities and work demands among public sector employees. L. Douglas Wilder School of Government \& Public Affairs, Commonwealth University Richmond, Virginia.

21. Kristensen, T.S. The soft guidelines of NIOH, Copenhagen. How to go from survey to action. Eighth International Congress of Behavioral Medicine. Integrating Social and Behavioral Sciences with Medicine and Public Health; 2004 Aug 25-28; Germany, Mainz. Retrieved Jun 21, 2014 from www.ami.dk/presentations

22. Borritz, M., Rugulies, R., Christensen, K.B., Villadsen, E. \& Kristensen, T.S. (2006). Burnout as a predictor of self-reported sickness absence among human service workers: prospective findings from three year follow up of the PUMA study. Occup Environ Med. 63(2), 98-106. DOI: 10.1136/oem.2004.019364.

23. Kroenke, K., Spitzer, R.L. \& Williams, J.B. (2001). The PHQ-9: validity of a brief depression severity measure. Journal of general internal medicine. 16(9), 606-13. DOI: 10.1046/j.1525-1497.2001.016009606.x.

24. Greenglass, E. R., Schwarzer, R., \& Taubert, S. (1999). The Proactive Coping Inventory (PCI): A multidimensional research instrument. Retrieved Jun 21 2014, from http://www.psych.yorku.ca/greenglass/

25. Horn, Charmaine Rebekka. (2014). Sense of coherence, work locus of control and burnout amongst mid-level managers in underground coal mining operations in Mpumalanga. Dissertation, (Industrial and Organisational Psychology) University of South Africa, Pretoria.

26. Van der Walt, M., \& Rieker, M.J. (2008). Job demands, job resources, burnout and engagement of employees in the mining industry in South Africa. Dissertation (M.A. (Industrial Psychology)), North-West University, Potchefstroom Campus, South Africa. 
27. Roets, Hanelie (2004). Burnout, job stress and sense of coherence in the coal mining industry. Dissertation (M.A. (Industrial Psychology)), North-West University, Potchefstroom Campus, South Africa.

28. Uysal, H.T. \& Kesim, E. (2015). Correlation Analytics of Blue-Collar Employees' Organizational Levels in Coal Mining. Open Journal of Business and Management. 3, 83-95. DOI: http://dx.doi.org/10.4236/ojbm.2015.31009.

29. Arandjelović, M., et al. (2010). Burnout and the quality of life of workers in food industry - a pilot study in Serbia. Vojnosanit Pregl. 67(9), 705-711.

30. Lešić, A., et al. (2009). Burnout in Belgrade orthopaedic surgeons and general practitioners, a preliminary report. ACI.56(2), 53-59. DOI:10.2298/ACI0902053L.
31. Vićentić, S., et al. (2010). Professional stress in general practitioners and psychiatrists - the level of psycologic distress and burnout risk. Vojnosanit Pregl. 67(9): 741-746.

32. Wu, Z., Wang, Q. \& Li, J. (2009). Investigation on the status and related factors of the mental health of coal miners who worked underground. Chin J Health Psychol 2009; 17: 1508-10 (in Chinese).

33. Marchand, A. (2007). Mental health in Canada: Are there any risky occupations and industries? International Journal of Law and Psychiatry. 30(4-5), 272-283. DOI:10.1016/j.ijlp.2007.06.002.

34. McLean, K.N. (2012). Mental health and well-being in resident mine workers: out of the fly-in fly-out box. Aust J Rural Health. 20: 126-30. DOI: 10.1111/j.1440-1584.2012.01267.x. 